\title{
Analysis of the typical small watershed of warping dams in the sand properties
}

\author{
LiLi $^{1,2, *}$, Ji Shan Yang ${ }^{2}$, Wei Ying Sun ${ }^{2}$, and Sha Sha Shen ${ }^{2}$ \\ ${ }^{1} \mathrm{Xi}$ 'an University of technology, Xi'an, Shanxi 710048, China \\ ${ }^{2}$ Key Laboratory of Soil and Water Loss Process and Control on the Loess Plateau of Ministry of Water Resources, Yellow River \\ Institute of Hydraulic Research, Zhengzhou 450003, China
}

\begin{abstract}
Coarse sediment with a particle size greater than $0.05 \mathrm{~mm}$ is the main deposit of riverbed in the lower Yellow River, the Loess Plateau is one of the concentrated source of coarse sediment, warping dam is one of the important engineering measures for gully control. Jiuyuangou basin is a typical small basin in the first sub region of hilly-gullied loess region, twenty warping dams in Jiuyuangou basin was selected as research object, samples of sediment along the main line of dam from upper, middle to lower reaches of dam fields and samples of undisturbed soil in slope of dam control basin were taken to carry out particle gradation analysis, in the hope of clearing reducing capacity on coarse sediment of different types of warping dam through the experimental data. The results show that the undisturbed soil in slope of dam control basin has characteristics of standard loess, the particle size are mainly distributed in $0.025 \sim 0.05 \mathrm{~mm}$, and the $0.05 \mathrm{~mm}$ particle size of Jiuyuangou basinof loess is an obvious boundary; Particle size of sediment in 15 warping dam of Jiuyuangou basin are mainly distributed in $0.031 \sim 0.05 \mathrm{~mm}$ with the dam tail is greater than dam front in general. The separation effect of horizontal pipe drainage is better than shaft drainage for which particle size greater than $0.05 \mathrm{~mm}$, notch dam is for particle size between $0.025 \sim 0.1 \mathrm{~mm}$, and fill dam is for particle size between $0.016 \sim 0.1 \mathrm{~mm}$, they all have a certain function in the sediment sorting.
\end{abstract}

\section{Introduction}

Nearly $50 \%$ of the silt in the river channel of the lower reaches of the Yellow River is coarse sediment with a particle size $>0.05 \mathrm{~mm}$, the main channel sediment and coarse sediment particle size greater than $0.05 \mathrm{~mm}$ over $70 \%$. Coarse sediment is the main source of sediment in the main lower reaches of the Yellow Rive[1]-[3], Jiuyuangou basin is a source of one of the coarse sand in the middle reaches of the Yellow River[4], The warping dam is one of the main maintain soil engineering measures in the basin[2]-[4], It plays an important role in reducing sediment deposition in the lower reaches [5][9].Sediment in 15 warping dams of Jiuyuangou dam sample through the probe hole method[10], At the same time,the original soil sampling in the dam control basin,then particle gradation analysis of samples, the difference of different types of silt Engineering Dam in Jiuyuangou dam to clear sediment sorting, in particular, the separation difference between coarse sediment with a particle size greater than $0.05 \mathrm{~mm}$. On the transformation of warping dam structure in the future, extend the dam of the deposition period and service life, all have a positive effect.

\section{The Study Area and The Sampling Method}

\subsection{The Study Area}

Jiuyuangou watershed's a ditch that is located middle and downstream area in the middle reaches of the Yellow River's Wuding River on the left bank. Jiuyuangou watershed is The typical small watershed about first sub region of Loess Hilly Region.Channel section is in a V shape.The main channel length is Eighteen $\mathrm{km}$. Average gradient of the channel is $1.15 \%$, gully density is $5.34 \mathrm{~km} / \mathrm{km}^{2}$, sea level elevation is $820-1180 \mathrm{~m}$, the catchment area is $70.10 \mathrm{~km}^{2}$. Jiuyuangou watershed is extremely severe erosion area.

\subsection{The Sampling Method}

Selection twenty dams in Jiuyuangou watershed(refer with: Table 1), along the line of dam in middle thread of channe, upstream, midstream and downstream of the layout of a sampling point, in the upstream, midstream and downstream of the layout of a sampling point, through the adjustable length of Luoyang shovel sampling, common deep $2 \mathrm{~m}$, the weight of each sample sample is about $0.5 \mathrm{~kg}$, and control of basin slope sampling sampling dam, sampling once per $0.05 \mathrm{~m}$, common deep $0.15 \mathrm{~m}$.

\footnotetext{
* Corresponding author: 47994494@qq.com
} 
Table 1. The Main Sampling Jiuyuangou Watershed Check Dam Situation

\begin{tabular}{|c|c|c|c|c|c|}
\hline $\begin{array}{l}\text { Name of } \\
\text { the dam }\end{array}$ & $\begin{array}{c}\text { Basin } \\
\text { unit } \\
\text { Watersh } \\
\text { ed }\end{array}$ & $\begin{array}{l}\text { Type } \\
\text { of } \\
\text { dam }\end{array}$ & $\begin{array}{c}\text { contr } \\
\text { ol } \\
\text { area } \\
\text { of } \\
\text { wate } \\
\text { rshe } \\
\text { d } \\
(\mathbf{k} \\
\left.\mathbf{m}^{2}\right)\end{array}$ & $\begin{array}{c}\text { Draina } \\
\text { ge } \\
\text { works }\end{array}$ & $\begin{array}{c}\text { Influ } \\
\text { ence } \\
\text { of } \\
\text { upst } \\
\text { rea } \\
\text { m } \\
\text { dam }\end{array}$ \\
\hline $\begin{array}{c}\text { Weijiayan } \\
\text { 3\# dam }\end{array}$ & Hejiagou & $\begin{array}{c}\text { Small } \\
\text { dam }\end{array}$ & 0.85 & $\begin{array}{c}\text { Nothin } \\
\mathrm{g}\end{array}$ & no \\
\hline $\begin{array}{l}\text { Hejiagou } \\
\text { 2\# dam }\end{array}$ & Hejiagou & $\begin{array}{l}\text { Key } \\
\text { dam }\end{array}$ & 1.69 & Aven & yes \\
\hline $\begin{array}{c}\text { Hejiagou } \\
1 \# \text { dam }\end{array}$ & Hejiagou & $\begin{array}{c}\text { Small } \\
\text { dam }\end{array}$ & 0.11 & $\begin{array}{c}\text { Nothin } \\
\mathrm{g}\end{array}$ & no \\
\hline $\begin{array}{c}\text { Weijiayan } \\
\text { 1\# dam }\end{array}$ & Hejiagou & $\begin{array}{c}\text { Small } \\
\text { dam }\end{array}$ & 0.16 & $\begin{array}{c}\text { Nothin } \\
\mathrm{g}\end{array}$ & yes \\
\hline $\begin{array}{l}\text { Laolimo } \\
\text { dam }\end{array}$ & $\begin{array}{c}\text { Maliango } \\
\mathrm{u}\end{array}$ & $\begin{array}{l}\text { Mediu } \\
\mathrm{m} \text { dam }\end{array}$ & 1.36 & $\begin{array}{l}\text { Horizo } \\
\text { ntal } \\
\text { pipe }\end{array}$ & yes \\
\hline $\begin{array}{l}\text { Maliangou } \\
\text { key dam }\end{array}$ & $\begin{array}{c}\text { Jiuyuang } \\
\text { ou }\end{array}$ & $\begin{array}{l}\text { Key } \\
\text { dam }\end{array}$ & 2.43 & $\begin{array}{c}\text { Horizo } \\
\text { ntal } \\
\text { pipe }\end{array}$ & yes \\
\hline $\begin{array}{l}\text { Haojialian } \\
\text { g dam }\end{array}$ & Xiyangou & $\begin{array}{l}\text { Key } \\
\text { dam }\end{array}$ & 2.69 & $\begin{array}{l}\text { Horizo } \\
\text { ntal } \\
\text { pipe }\end{array}$ & yes \\
\hline $\begin{array}{c}\text { Xiyangou } \\
\text { Mizoguchi } \\
\text { dam }\end{array}$ & Xiyangou & $\begin{array}{l}\text { Key } \\
\text { dam }\end{array}$ & 2.43 & $\begin{array}{c}\text { Spillwa } \\
\mathrm{y}\end{array}$ & yes \\
\hline $\begin{array}{c}\text { Xiyangou } \\
\text { Village } \\
\text { front dam }\end{array}$ & Xiyangou & $\begin{array}{l}\text { Mediu } \\
\mathrm{m} \text { dam }\end{array}$ & 1.81 & $\begin{array}{l}\text { Horizo } \\
\text { ntal } \\
\text { pipe }\end{array}$ & yes \\
\hline $\begin{array}{c}\text { Tanyanggo } \\
\text { u dam }\end{array}$ & Xiyangou & $\begin{array}{l}\text { Gap } \\
\text { dam }\end{array}$ & 0.29 & $\begin{array}{c}\text { Nothin } \\
\mathrm{g}\end{array}$ & no \\
\hline $\begin{array}{c}\text { Mazhangz } \\
\text { ui dan }\end{array}$ & Lijiazhai & $\begin{array}{l}\text { Key } \\
\text { dam }\end{array}$ & 0.99 & $\begin{array}{c}\text { Horizo } \\
\text { ntal } \\
\text { pipe }\end{array}$ & no \\
\hline $\begin{array}{c}\text { Fanshan } \\
\text { dam }\end{array}$ & Lijiazhai & $\begin{array}{l}\text { Mediu } \\
\text { m dam }\end{array}$ & 2.16 & Aven & no \\
\hline $\begin{array}{c}\text { Beitagou } \\
\text { dam }\end{array}$ & $\begin{array}{c}\text { Wangma } \\
\text { ogou }\end{array}$ & $\begin{array}{c}\text { Small } \\
\text { dam }\end{array}$ & 0.19 & $\begin{array}{c}\text { Nothin } \\
\mathrm{g}\end{array}$ & no \\
\hline $\begin{array}{c}\text { Guandigou } \\
\text { 3\# dam }\end{array}$ & $\begin{array}{c}\text { Wangma } \\
\text { ogou }\end{array}$ & $\begin{array}{c}\text { Small } \\
\text { dam }\end{array}$ & 0.12 & Aven & no \\
\hline $\begin{array}{c}\text { Guandigou } \\
\text { 2\# dam }\end{array}$ & $\begin{array}{c}\text { Wangma } \\
\text { ogou }\end{array}$ & $\begin{array}{c}\text { Small } \\
\text { dam }\end{array}$ & 0.2 & $\begin{array}{l}\text { Nothin } \\
\text { g }\end{array}$ & no \\
\hline $\begin{array}{c}\text { Guandigou } \\
4 \# \text { dam }\end{array}$ & $\begin{array}{c}\text { Wangma } \\
\text { ogou }\end{array}$ & $\begin{array}{l}\text { Mediu } \\
\text { m dam }\end{array}$ & 0.41 & Aven & no \\
\hline $\begin{array}{l}\text { Wangbogo } \\
\text { u 2\# dam }\end{array}$ & $\begin{array}{l}\text { Wangma } \\
\text { ogou }\end{array}$ & $\begin{array}{c}\text { Small } \\
\text { dam }\end{array}$ & 0.17 & Aven & no \\
\hline $\begin{array}{c}\text { Nianyango } \\
\text { u 4\# dam }\end{array}$ & $\begin{array}{c}\text { Wangma } \\
\text { ogou }\end{array}$ & $\begin{array}{c}\begin{array}{c}\text { Small } \\
\text { dam }\end{array} \\
\end{array}$ & 0.21 & $\begin{array}{c}\text { Nothin } \\
\mathrm{g}\end{array}$ & no \\
\hline $\begin{array}{c}\text { Sdizui 2\# } \\
\text { dam }\end{array}$ & $\begin{array}{c}\text { Wangma } \\
\text { ogou }\end{array}$ & $\begin{array}{c}\text { Small } \\
\text { dam }\end{array}$ & 0.59 & Aven & no \\
\hline $\begin{array}{c}\text { Guandigou } \\
1 \# \text { dam }\end{array}$ & $\begin{array}{l}\text { Wangma } \\
\text { ogou }\end{array}$ & $\begin{array}{l}\text { Mediu } \\
\mathrm{m} \text { dam }\end{array}$ & 1.11 & Aven & yes \\
\hline
\end{tabular}

\section{Analysis of Grain Size of Original Loess in Jiuyuangou Watershed}

Table 2 shows that the Jiuyuangou watershed of loess gives first place to silt particles $(0.05 \sim 0.005 \mathrm{~mm})$.The change range of the soil mass percentage of fine sand $(>0.05 \mathrm{~mm})$ percentage of the silt size is $17.3 \sim 36 \%$, the change value is $18.7 \%$. The change range of the soil mass $(0.05 \sim 0.005 \mathrm{~mm})$ percentage of the silt particle size is $47 \sim 62.2 \%$, the change value is $15.2 \%$. The clay is 12.8 to $23.8 \%$, the change value is $11 \%$. The difference between the maximum and the minimum of the content of different particles is close.

The differences of average content of different sizes of Jiuyuangou watershed of loess in great. The average value of the soil mass $(>0.05 \mathrm{~mm})$ percentage of fine sand particle size is $27.6 \%$. The silt $(0.05 \sim 0.005 \mathrm{~mm})$ is $55.5 \%$. The clay $(<0.005 \mathrm{~mm}) \quad 17 \%$. In Jiuyuangou watershed of loess in silty soil, followed by sand, clay is again. The average soil mass percentage of $0.05 \sim 0.01 \mathrm{~mm}$ particle in silt is $46.4 \%$. The average soil mass percentage of $0.01 \sim 0.005 \mathrm{~mm}$ is $9.1 \%$., The coarse silt is more than 5 times that of the fine silt soil, and has the main characteristics of the standard loess.

Table 2 Analysis results of particle gradation of undisturbed soil in Jiuyuangou basin

\begin{tabular}{|c|c|c|c|}
\hline \multirow{2}{*}{$\begin{array}{l}\text { Sampling point of } \\
\text { original loess } \\
\text { in Dam control } \\
\text { basin }\end{array}$} & \multicolumn{3}{|c|}{$\begin{array}{l}\text { The particle size of soil mass less } \\
\text { than a particle size }(\mathrm{mm})\end{array}$} \\
\hline & $\begin{array}{l}>0.05 \mathrm{~m} \\
\mathrm{~m}\end{array}$ & $\begin{array}{c}0.05- \\
0.005 \mathrm{~m}\end{array}$ & $<0.005 \mathrm{~mm}$ \\
\hline Ge jia gou Dam & 27.8 & 56.6 & 15.6 \\
\hline $\begin{array}{l}\text { Wang mao gou Men } \\
\text { hu lu Dam }\end{array}$ & 36.0 & 47.3 & 16.7 \\
\hline $\begin{array}{l}\text { Wang mao gou Shu } \\
\text { jing Dam }\end{array}$ & 25.0 & 62.2 & 12.8 \\
\hline Wei jia yan 3\# dam & 28.3 & 50.0 & 21.7 \\
\hline He jia gou 2\# Dam & 30.8 & 54.0 & 15.2 \\
\hline He jia gou 1\# Dam & 20.4 & 61.3 & 18.3 \\
\hline Xi yan gou dan & 24.4 & 58.5 & 17.1 \\
\hline Hao jia liang dam & 35.4 & 47.0 & 17.6 \\
\hline Ma lian gou dam & 20.2 & 56.0 & 23.8 \\
\hline Lao li mao dam & 28.7 & 58.4 & 12.9 \\
\hline Ma zhang zui dam & 25.3 & 57.5 & 17.2 \\
\hline Fan shan dam & 32.6 & 52.9 & 14.5 \\
\hline $\begin{array}{c}\text { Xia qiao gou 3\# } \\
\text { dam }\end{array}$ & 28.8 & 55.6 & 15.6 \\
\hline $\begin{array}{c}\text { Xia qiao gou 2\# } \\
\text { dam }\end{array}$ & 32.3 & 54.0 & 13.7 \\
\hline Xiang ta gou dan & 17.3 & 60.6 & 22.2 \\
\hline minimum value & 17.3 & 47.0 & 12.8 \\
\hline Maximum value & 36.0 & 62.2 & 23.8 \\
\hline Average value & 27.6 & 55.5 & 17.0 \\
\hline
\end{tabular}

\section{The Analysis of Different Types of Engineering Dam Sediment Particle}

According to the particle size analysis results(refer with: Table 3), the silt dams that the average particle size's in front of the dam is less than the dam tail in Jiuyuangou Watershed are seventeen, $81 \%$ of the total number; the silt dams that the average particle size's in front of the dam is close to the dam tail are three, $15 \%$ of the total number; the silt dams that the average particle size's in 
front of the dam staggeres distribution in the dam tail and intermediate are one, $5 \%$ of the total number. Therefore,the one silt dams will be get rid of the sampling analysis.

Table 3 Particle gradation analysis of sediment from 15 sampling warping dam in Jiuyuangou basin

\begin{tabular}{|c|c|c|c|c|c|}
\hline \multirow{2}{*}{ Dam name } & \multirow{2}{*}{ position } & \multicolumn{4}{|c|}{$\begin{array}{c}\text { The particle size of soil mass less than a } \\
\text { particle size }(\mathrm{mm})\end{array}$} \\
\hline & & $\begin{array}{c}<0.00 \\
1\end{array}$ & $\begin{array}{c}0.001 \sim \\
0.025\end{array}$ & $\begin{array}{c}0.025 \sim \\
0.050\end{array}$ & $>0.050$ \\
\hline \multirow{2}{*}{$\begin{array}{l}\text { Xi yan gou } \\
\text { cun qian } \\
\text { dam }\end{array}$} & $\begin{array}{c}\text { The } \\
\text { front of } \\
\text { the dam }\end{array}$ & 4.71 & 55.59 & 25.06 & 14.64 \\
\hline & Dam tail & 3.14 & 32.46 & 32.77 & 31.63 \\
\hline \multirow{2}{*}{$\begin{array}{l}\text { Hao jia } \\
\text { liang dam }\end{array}$} & $\begin{array}{c}\text { The } \\
\text { front of } \\
\text { the dam }\end{array}$ & 3.02 & 33.01 & 30.21 & 33.76 \\
\hline & Dam tail & 3.12 & 29.77 & 28.28 & 38.83 \\
\hline $\begin{array}{l}\text { Xi yan gou } \\
\text { gou kou } \\
\text { dam }\end{array}$ & $\begin{array}{l}\text { The } \\
\text { front of } \\
\text { the dam }\end{array}$ & 3.69 & 40.88 & 30.8 & 24.63 \\
\hline $\begin{array}{l}\text { Tan yang } \\
\text { gou dam }\end{array}$ & $\begin{array}{l}\text { The } \\
\text { front of } \\
\text { the dam }\end{array}$ & 3.5 & 36.24 & 31.92 & 28.34 \\
\hline \multirow[t]{2}{*}{$\begin{array}{l}\text { Ma lian } \\
\text { gou dam }\end{array}$} & $\begin{array}{c}\text { The } \\
\text { front of } \\
\text { the dam }\end{array}$ & 3.27 & 33.12 & 30.23 & 33.38 \\
\hline & Dam tail & 2.92 & 26.83 & 30.65 & 39.61 \\
\hline \multirow{2}{*}{$\begin{array}{l}\text { Lao li mao } \\
\text { dam }\end{array}$} & $\begin{array}{c}\text { The } \\
\text { front of } \\
\text { the dam }\end{array}$ & 3.36 & 42.91 & 30.36 & 23.36 \\
\hline & Dam tail & 3.52 & 39.42 & 29.44 & 27.62 \\
\hline \multirow[t]{2}{*}{$\begin{array}{l}\text { Ma zhang } \\
\text { zui dam }\end{array}$} & $\begin{array}{l}\text { The } \\
\text { front of } \\
\text { the dam }\end{array}$ & 4.15 & 47.41 & 28.64 & 19.81 \\
\hline & Dam tail & 3.21 & 35.31 & 30.5 & 30.99 \\
\hline \multirow[t]{2}{*}{$\begin{array}{c}\text { Fan shan } \\
\text { dam }\end{array}$} & $\begin{array}{c}\text { The } \\
\text { front of } \\
\text { the dam }\end{array}$ & 4.32 & 48.75 & 27.11 & 19.82 \\
\hline & Dam tail & 3.98 & 43.23 & 28.61 & 24.18 \\
\hline \multirow[t]{2}{*}{$\begin{array}{l}\text { Bei ta goui } \\
\text { dam }\end{array}$} & $\begin{array}{c}\text { The } \\
\text { front of } \\
\text { the dam }\end{array}$ & 4.38 & 57.63 & 25.64 & 12.35 \\
\hline & Dam tail & 3.17 & 32.59 & 33.36 & 30.88 \\
\hline \multirow{2}{*}{$\begin{array}{c}\text { Guan di } \\
\text { gou } 3 \# \\
\text { dam }\end{array}$} & $\begin{array}{c}\text { The } \\
\text { front of } \\
\text { the dam }\end{array}$ & 4.4 & 60.25 & 24.63 & 10.71 \\
\hline & Dam tail & 3.01 & 30.42 & 33.43 & 33.15 \\
\hline \multirow{2}{*}{$\begin{array}{l}\text { Guan di } \\
\text { gou } 2 \# \\
\text { dam }\end{array}$} & $\begin{array}{l}\text { The } \\
\text { front of } \\
\text { the dam }\end{array}$ & 4.5 & 55.88 & 23.88 & 15.74 \\
\hline & Dam tail & 3.69 & 37.03 & 29.48 & 29.8 \\
\hline $\begin{array}{c}\text { Guan di } \\
\text { gou 4\# } \\
\text { dam }\end{array}$ & $\begin{array}{l}\text { The } \\
\text { front of } \\
\text { the dam }\end{array}$ & 4.21 & 56.57 & 26.55 & 12.67 \\
\hline \multirow{2}{*}{$\begin{array}{l}\text { Wei jia } \\
\text { yan 3\# } \\
\text { dam }\end{array}$} & $\begin{array}{l}\text { The } \\
\text { front of } \\
\text { the dam }\end{array}$ & 3.67 & 36.22 & 28.6 & 31.51 \\
\hline & Dam tail & 3.31 & 31.1 & 28.27 & 37.33 \\
\hline \multirow[t]{2}{*}{$\begin{array}{l}\text { He jia gou } \\
\text { 2\# Dam }\end{array}$} & $\begin{array}{c}\text { The } \\
\text { front of } \\
\text { the dam }\end{array}$ & 4.67 & 55.02 & 25.08 & 15.24 \\
\hline & Dam tail & 3.8 & 40.63 & 28.3 & 27.27 \\
\hline $\begin{array}{c}\text { He jia gou } \\
\text { 1\# Dam }\end{array}$ & $\begin{array}{l}\text { The } \\
\text { front of } \\
\text { the dam }\end{array}$ & 3.89 & 40.97 & 27.98 & 27.15 \\
\hline
\end{tabular}

Sediment's size in front of the dam about Jiuyuangou Watershed's the 20 silt dams $>0.05 \mathrm{~mm}$ and $>$ $0.10 \mathrm{~mm}$,particle size volume arithmetic average percent respectively $22.41 \%$ and $3.07 \%$, Sediment's size in the dam tail $>0.05 \mathrm{~mm}$ and $>0.10 \mathrm{~mm}$, particle size volume arithmetic average percent respectively $32.07 \%$ and $4.89 \%$. Jiuyuangou Watershed's the average particle size distribution curve about in in front of the dam and the dam tail is Figure 1. According to the particle size analysis results, the coarse sadiment size of Jiuyuangou Watershed's silt dam concentrats mainly in $0.05 \mathrm{~mm}$.

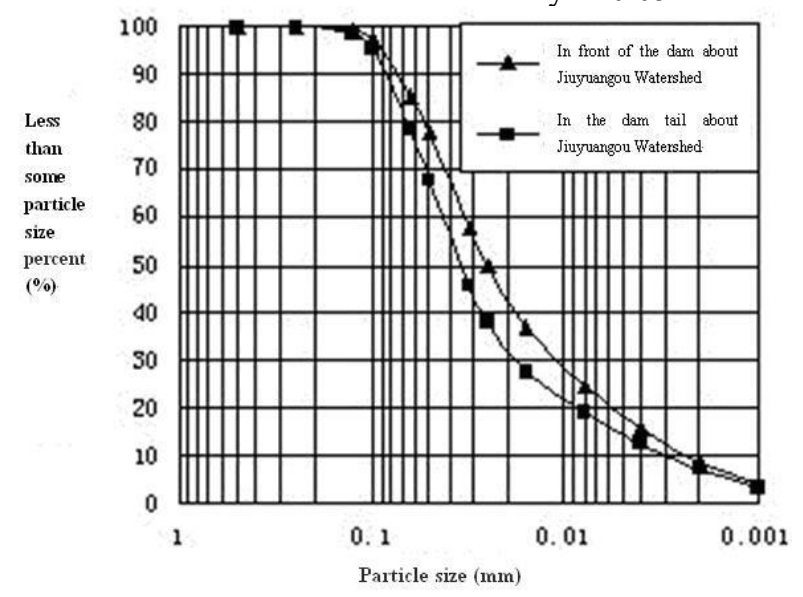

Figure 1 Average sediment grading curve in front of the dam and the dam tail about Jiuyuangou Watershed

According to the particle size analysis results(refer with: Table 3 ), in addition to tanyanggou que kou dam and xiyangou goukou dam, the average grain size distribution curve of the remaining 17 warping dams in the sediment of the display in front of the dam is located below the dam end curve curve shows that the average grain size of sediment in front of the dam is less than the tail dam (refer with: Figure 2). The proportion of sediment particle size at $0.031 \mathrm{~mm} \sim 0.001 \mathrm{~mm}$, the drainage dam is greater than no drainage dam. The proportion of sediment with a sediment particle size larger than $0.05 \mathrm{~mm}$, the drainage dam is less than no drainage dam. The proportion of sediment particle size at $0.05 \mathrm{~mm} \sim 0.031 \mathrm{~mm}$, no drainage dam and drainage dam is basically the same. Thus it can be seen,In front of the dam, the drainage dam is greater than no drainage dam in separation of coarse sediment with a particle size larger than $0.05 \mathrm{~mm}$ (refer with: Figure 3).

At the front of the dam, the difference of sediment sorting is mainly because there is no drainage engineering dam for the upstream flood carrying sediment basically is retaining, the sediment concentration flood after the dam can not be discharged in time, the fine sediment carried by the flood is fully deposited, the drainage dam project is through the shaft or horizontal pipe part of the late deposition of fine sediment transported downstream. Therefore, sand in front of the drainage dam is crude than the no drainage dam. 


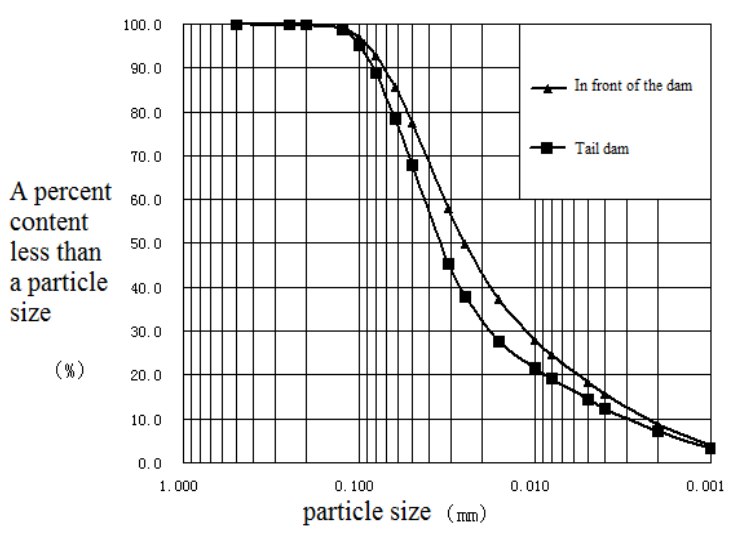

Figure 2 Average particle gradation curve of sediment from dam front and tail of 13 warping dam

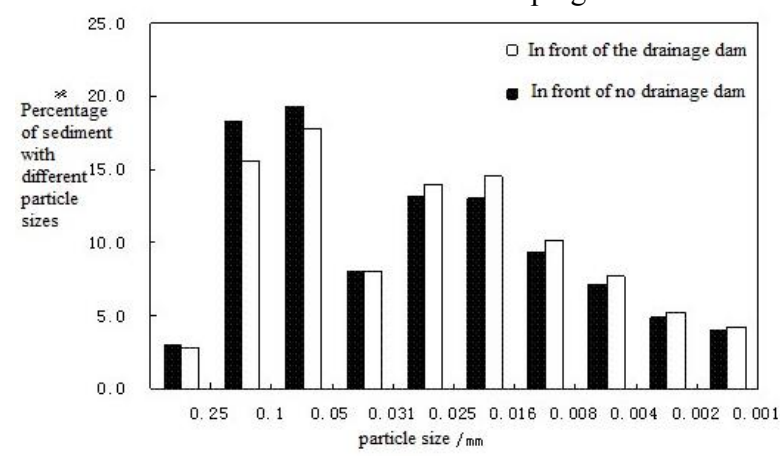

Figure 3 Variation in proportion of different particle size of sediment from dam in front of warping dam with drainage works and no drainage works

The proportion of grain size of mud and sand in front of the tanyangou dam from $0.025 \mathrm{~mm}$ to $0.001 \mathrm{~mm}$, lower than the original soil in front of the dam. The proportion of particle size in $0.1 \mathrm{~mm} \sim 0.025 \mathrm{~mm}$, the front of the dam is larger than the original soil. The proportion of sediment particle size from $0.25 \mathrm{~mm}$ to $0.1 \mathrm{~mm}$, lower than the original soil in front of the dam.So, in front of the tanyanggou dam, on the particle size in $0.1 \mathrm{~mm} \sim$ $0.025 \mathrm{~mm}$ has a certain role in the sediment sorting. The proportion of sediment in the mud and sand grains in the front of the xiyangou goukou dam from $0.1 \mathrm{~mm}$ to $0.016 \mathrm{~mm}$, the front of the dam is larger than the original soil. The proportion of sediment particle size from $0.016 \mathrm{~mm}$ to $0.001 \mathrm{~mm}$ and $0.25 \mathrm{~mm}$ to $0.1 \mathrm{~mm}$, Lower than the original soil in front of the dam. So, the silt filled dam has a certain sorting effect on the $0.1 \mathrm{~mm} \sim$ $0.016 \mathrm{~mm}$ sediment in the upper reaches.

Table 4 shows that the particle size is greater than $0.05 \mathrm{~mm}$ of sediment, horizontal pipe dam drainage optimal separation effect.

Table 4 Proportion sorting of sediment in different types of warping dam

\begin{tabular}{|c|c|c|c|c|c|c|}
\hline \multirow{2}{*}{$\begin{array}{c}\text { The type of } \\
\text { dam } \\
\text { engineering }\end{array}$} & \multicolumn{2}{|c|}{$\mathrm{d}_{\mathrm{yu}}(\%)$} & \multicolumn{2}{c|}{$\mathrm{d}_{\mathrm{yuan}}(\%)$} & \multicolumn{2}{c|}{$\mathrm{d}_{\mathrm{yu}} / \mathrm{d}_{\mathrm{yuan}}(\%)$} \\
\cline { 2 - 7 } & $\begin{array}{c}\mathrm{d}>0.05 \\
\mathrm{~mm}\end{array}$ & $\begin{array}{c}\mathrm{d}>0.1 \\
\mathrm{~mm}\end{array}$ & $\begin{array}{c}\mathrm{d}>0.05 \\
\mathrm{~mm}\end{array}$ & $\begin{array}{c}\mathrm{d}>0.1 \\
\mathrm{~mm}\end{array}$ & $\begin{array}{c}\mathrm{d}>0.05 \\
\mathrm{~mm}\end{array}$ & $\begin{array}{c}\mathrm{d}>0 . \\
1 \mathrm{~mm}\end{array}$ \\
\hline $\begin{array}{c}\text { Drainage } \\
\text { pipe } \\
\text { drainage }\end{array}$ & 26.0 & 4.4 & 21.9 & 3.5 & 118.7 & $\begin{array}{c}125 . \\
7\end{array}$ \\
\hline $\begin{array}{c}\text { Shaft } \\
\text { drainage }\end{array}$ & 20.7 & 3.5 & 21.2 & 3.5 & 97.6 & $\begin{array}{c}100 . \\
0\end{array}$ \\
\hline $\begin{array}{c}\text { No } \\
\text { drainage }\end{array}$ & 23.0 & 4.2 & 24.8 & 5.5 & 92.7 & 76.4 \\
\hline
\end{tabular}

\begin{tabular}{|c|l|l|l|l|l|l|}
\hline project & & & & & & \\
\hline
\end{tabular}

Explain: $d_{y u}$ is the arithmetic mean of the percentage of the sediment particle size greater than $0.05 \mathrm{~mm}$ and $0.1 \mathrm{~mm}$ in dam $\mathrm{d}_{\text {yuan }}$ is the arithmetic mean of the percentage of the sediment particle size greater than $0.05 \mathrm{~mm}$ and $0.1 \mathrm{~mm}$ in basin of Original loess

\section{Conclusion}

First, Jiuyuangou undisturbed soil particle size was mainly distributed in $0.025 \sim 0.05 \mathrm{~mm}$, the coarse silt is more than 5 times the fine silt, with standard features of loess; warping dams in sediment particle size mainly distributed in $0.031 \sim 0.05 \mathrm{~mm}$.

Second, At the end of the dam, there is little difference in the average particle size of silt in the dam drainage project danm and no drainage project dam. In front of the dam, dam separation effect is better than coarse sand dam drainage engineering for particles of size greater than $0.05 \mathrm{~mm}$ without drainage engineering. The dam dam is better than vertical drainage drainage sorting horizontal coarse sediment particle size is greater than $0.05 \mathrm{~mm}$ of the tube.

Third, the tanyanggou dam has certain sorting effect on the sediment with particle size ranging from $0.1 \mathrm{~mm}$ to $0.025 \mathrm{~mm}$. The silted xiyangou goukou dam has certain sorting effect on the sediment with particle size from $0.1 \mathrm{~mm}$ to $0.016 \mathrm{~mm}$.

\section{Acknowledgments}

This paper is based on work supported by the Central Nonprofit Research Institutions Basic Scientific Research Special Fund(HKY-JBYW-2018-08).

\section{References}

1. HUI Bo, LI Peng, ZHANG Wei, et al. Distribution characteristics of soil particles and organic carbon on check-dam system in Wangmaogou watershed[J]Research of Soil and Water Conservation, .2015, 22(4): 1-5.

2. ZUO Zhongguo, CHEN Hong, WANG Xiaobing, XU Jianhua, et al. Effect of warping dam in siltladen and coarse sand region of the middle yellow river to sediment grading[J]. Yellow River, 2007, 29(2): 64-66.

3. LI Mian, YANG Jianfeng, HOU Jiancai, SHEN Zhongyuan. Sediment deposition process for a silt dam in a small watershed in Loess Hilly Region [J]. Transactions of the CSAE, 2008,24(2): 64-69.

4. XU Jianhua, LIN Yinping, WU Chengji, YU Quangang, et al. Research on boundary division of coarse sand concentrated source region of the middle Yellow River[M]. The Yellow River Water Conservancy Press, 2006.

5. QIAN Yunping, LIN Yinping, DONG Xuena, et al. Analysis of coarse sediment modulus change and sediment yield in the coarse sediment area in the 
Yellow River from 1855 to $1995[\mathrm{~J}]$. Yellow River, 1998, 20(40): 15-18.

6. HAN Peng, NI Jinren. Grain size variation of suspended sediment due to soil conservation in the middle reach of Yellow River[J]. SHUILI XUEBAO, 2001(8): 69-74.

7. RAN Dachuan, ZUO Zhongguo, SHANGGUAN Zhouping. Effect of check dam on retaining and reducing coarse grain sediment in middle reaches of Yellow River [J]. SHUILI XUEBAO, 2006, 37(4): 443-450.

8. ZHANG Wei, YANG Mingyi, ZHANG Fengbao,ZHANG Jiaqiong,ZHAO Tianyin et al. Profile distribution of particle size of sediment at a check dam in a small watershed of the Loess Plateau[J]Research of Soil and Water Conservation, .2015, 22(2): 17-21.

9. LIU Huifang, CAO Wenhong, QIN Wei, ZHANG Xiaoming. The Contribution of Silt Dam for Soil and Water Conservation Measures [J]China Rural Water and Hydropower, 2011(1): 55-59.

10. LI Li, SUN Weiying, SHI Xuejian. Analysis of sedimentgrain size of warping dams in Jiuyuangou and Tuwei river watersheds [J]. Yellow River, 2014, 36(5): 79-81.Luigi T. De Luca, Propulsion physics (EDP Sciences, Les Ulis, 2009) 